\title{
Advocacy Be Not Forsaken! Retrospective Lessons from Welfare Reform
}

\author{
by Vicki Lens \& Margaret Gibelman
}

\begin{abstract}
This article reviews the often uneven and sometimes peripheral role of advocacy as a social work function and explores its current relevan$c y$ in regard to agency practices, ethical mandates and the "person-in-environment" orientation of social work practice. Welfare reform (in which Aid to Families with Dependent Children [AFDC] was abolished in 1996 and replaced with Temporary Assistance for Needy Families [TANF]) is presented as a case example of both a failed opportunity to influence the course of public debate, and the potential benefits of advocacy when it is systematically applied and integrated as part of an overall organizational approach to services. Generalized principles are then drawn from the case study as they apply to advocacy practice with vulnerable populations.
\end{abstract}

INDIVIDUAL RESPONSIBILITY. Privatization. Local control. Managed care. Smaller government. These dominant themes provide the framework for the social service delivery system of the new millennium and, in combination, suggest the magnitude of the accommodations demanded on the part of the social welfare community. The traditional role of nonprofit and public social service agencies in caring for the most vulnerable citizens has been severely compromised by the overriding political objective of "doing more with less," often resulting in simply doing less for those in need.

Adaptations in the modus operandi of social welfare organizations as a result of changing socio-political values have resulted in a service focus which emphasizes efficient, short-term, immediate results- oriented interventions (Emenhiser, King, Joffe, \& McCullough, 1998) aimed at "perfecting the individual" rather than "perfecting society" (Specht \& Courtney, 1994, p. 4.) Billable hours count, and the one social work strategy that might protect the broader interests of at-risk populations -advocacy-is not among the billable services.

This article reviews the often uneven and sometimes peripheral role of advocacy as a social work function, a history which is rooted in the development of the profession and which retains its centrality, at least in principle, through the Code of Ethics (NASW, 1996a). Welfare reform (in which Aid to Families with Dependent Children [AFDC] was abolished in 1996 and replaced with Temporary Assistance for Needy Families [TANF]) is presented as a case example of both a failed opportunity to influence the course of public debate and the potential benefits of advocacy when it is systematically applied and integrated as part of an overall organizational approach to services and a problem-solving strategy. Generalized principles are then drawn from the case study as they apply to advocacy practice with vulnerable populations. The focus is on advocacy at the agency level.

\section{The Advocacy Mandate}

Advocacy has been defined as "the act of directly representing or defending others" (Barker, 1999, p. 11). Within social work, advocacy can be oriented to the "case" or "cause" level. Case advocacy refers to actions taken with or on behalf of a particular client or group of clients; cause or social advocacy refers to actions that are initiated to address a common issue or problem affecting groups of people (Council on Accreditation [COA], 1997). Enabling, brokering, mediating, and educating are among the advocacy interventions that may be employed to achieve change in the socio-economic and/or political conditions that affect the well-being of clients (Mickelson, 1995; Barker, 1999).

Families in Society: The Journal of Contemporary Human Services

Copyright 2000 Families International, Inc. 
The Code of Ethics of the National Association of Social Workers (1996a) identifies advocacy as a basic obligation of the profession and its members:

Social workers should engage in social and political action that seeks to ensure that all persons have equal access to the resources, employment, services, and opportunities that they require in order to meet their basic buman needs and to develop fully. Social workers should be aware of the impact of the political arena on practice, and should advocate for changes in policy and legislation to improve social conditions in order to meet basic human needs and promote social justice (NASW, 1996a, p. 27).

The involvement of social workers in advocacy has waxed and waned throughout the profession's history. Mobilization for advocacy tends to occur (1) when government offers programs and financial incentives for advocacy, exemplified in the War on Poverty programs, or (2) when there is a threat to the continuation of entrenched and deeply vested health and human service programs, exemplified in the Reagan administration's assault on the totality of the social welfare system, and continued through the Bush presidency. In such instances, mobilization for advocacy comes from within the social welfare community itself, both out of selfnterest and on behalf of clients.

The history of American social welfare policy evidences a consistent pattern of ambivalence about longterm commitments to social programs for vulnerable populations. Thus, threats or the actuality of funding cuts and program retrenchment are not new to human service agencies, their personnel, and the clients served. During such times, the professional literature, in concert with the liberal media, has embraced advocacy as both a fundamental responsibility and effective strategy (Kahn, 1991; Haynes \& Mickelson, 1996). But advocacy selectively applied during periods of crisis stems the tide, if at all, for only a short duration and fails to address systemic barriers that impact upon the clients served. We know with some certainty that the cycles of budget and program cuts will occur, but collectively, social workers approach each new assault as if it were an unanticipated and isolated event, rather than part of a larger socio-political pattern. A more integrated approach to advocacy is needed at all levels of practice to ensure a level of preparedness and effective response before, not after the "ax" has fallen.

\section{The Case of Welfare Reform: Missed Opportunity}

The promise of welfare reform was a dominant theme and big news during the presidential debates of 1992. When Bill Clinton assumed the presidency in 1993, his promise to "end welfare as we know it," was greeted with enthusiasm from both sides of the political spectrum, although each side in the debate was motivated by disparate values and agendas (Cammisa, 1998). Even social workers were in favor of an overhaul of the system, largely, however, on the basis of its inadequacies and the desire to better address the needs of the poor (Abbott, 1993; Hartman, 1993; Staff, 1993).

The abolishment of AFDC in 1996 and its replacement with TANF, subsumed under the Personal Responsibility and Work Opportunity Reconciliation Act of 1996 (P.L.104-193), turned "welfare" into a highly restrictive block grant program, limiting aid to five years, requiring states to force recipients into the work force, and mandating penalties against states and recipients if they did not comply (NASW, 1996b; Super, Parrott, Steinmetz, \& Mann, 1996).

TANF left virtually no corner of the social service marketplace unaffected. The fact that AFDC funded not only direct entitlements (welfare grants) to individuals, but also paid, through Medicaid, for a range of social services provided by social workers, was not immediately grasped. Clearly a more concerted and organized advocacy attempt was required in order to prevent the abolishment of a program that affected the lives of many of the clients served across the spectrum of agencies -from the traditional public welfare bureaucracies to nonprofit shelters, mental health and substance abuse programs, and immigrant services.

While many organizations representing social work interests, including the National Association of Social Workers and Child Welfare League of America, rallied against the passage of TANF, their voices were infrequently heard. The absence of advocates was so conspicuous that even elected officials complained that there was "very little mail, very few phone calls, and only muted lobbying on behalf of their position" (Havemann, 1995, p. A11). Advocates themselves decried their lack of influence, claiming they had been locked out of the debate (Vobejda \& Havemann, 1995, p. A4). When social welfare advocates were heard, the message was often ineffective; rather than emphasizing hard facts and constructive alternatives, advocates argued to maintain the status quo, a stance that was simply ineffective and out 
of tune with the political pulse (Lens, 2000). One newspaper headline decried: "social workers could undermine welfare reform," and noted that NASW had "opposed all efforts to trim welfare benefits and to require work" (Payne, 1996, p. A16). The social welfare community was portrayed as a negative force against positive change. A retrospective analysis provides important clues as to the options the social work community might have exercised and helps prepare us for the next-and inevitable -series of policy changes and their potential impact on clients.

\section{An Advocacy Mindset}

\section{Administrative Sanction}

Agencies are crucial, but often absent, players in attempts to influence policies that affect clients. The use of advocacy as a practice intervention requires administrative sanction and such sanction is often lacking (Gibelman \& Kraft, 1996). As noted earlier, reimbursement formulas increasingly dictate what interventions may be used to address particular problems. DSM-IV diagnoses are typically required; this clinical focus narrows the potential repertoire of interventions that the social worker may employ. The funding base of most human service agencies, predicated on a managed care model with its emphasis on short-term treatment and prescribed outcome goals, constrain the range of practice technologies that may be approved or promoted by the agency.

Another constraint is found in the limitations on nonprofit agencies in regard to the types of advocacy activities in which they may engage and the proportion of income that may be used for such purposes. The Internal Revenue Service has become increasingly vigilant about monitoring the activities of 501 (c)(3) charitable organizations that seek to influence, directly or indirectly, legislation (Harmon, Ladd, \& Evans, 1997; Schadler, 1997). The risk of the ultimate IRS sanction-withdrawal of tax-exempt status-may lead agencies to shun any form of advocacy activity. However, although lobbying is regulated, there are many legitimate forms of advocacy that are permissible (Hopkins, 1991; Smucker, 1991). In fact, the Council of Accreditation for Services to Families and Children, one national accrediting body for social service agencies, includes among its standards that the organization provides for case advocacy on behalf of individuals or families as well as for cause advocacy with regard to priority issues affecting significant numbers of those served (1997, p.4). Thus, constraints do not translate to prohibitions.
The propensity to incorporate advocacy as an intervention in clinical practice depends, in part, on the practitioner's mind-set or orientation. Education for social work practice is predicated upon the fundamental theoretical premise of person-in-environment (Council on Social Work Education, 1994). Nevertheless, studies of the career development of social workers suggest that there is a strong tendency for clinicians to approach interventions from a psychological, rather than a psychosocial perspective (Specht \& Courtney, 1994; Gibelman $\&$ Schervish, 1996). One can assume that, through formal education, social workers have acquired the skills to integrate advocacy into clinical practice, only choose not to do so. This assumption is not disparaging, but rather is rooted in reimbursement formulas as well as the personal preferences of many social workers (Gibelman \& Schervish, 1997).

Although the model of practice typically followed in social service agencies is dominated by a clinical emphasis, an agency may promote advocacy as a direct service intervention in several ways. Case planning procedures may require that advocacy strategies be specified. Case conferences may include attention to environmental factors affecting the client situation and how these may be addressed. For services the agencies provides under contract, staff review of reporting requirements, such as notifying the public agency if a client misses an appointment, can red-flag situations in which clients may be at-risk of punitive action. Agency staff can then explore how, within the limits of their contractual obligations, they can flexibly meet such reporting requirements in a way that lessens the adverse impact on clients. Time at staff meetings can be set aside to update clinicians about pending legislative changes at the state or federal level that may affect agency clients, with discussion of what information the agency might provide for consideration in legislative deliberations.

Most agencies already have in place record keeping procedures that permit quick access to information that may counter negative stereotypes about clients or demonstrate the harm that various proposals may cause. They are in the position of being able to document and quantify what these individuals and groups need and how they are being affected by social policy. For example, are there clients who have lost housing due to a work sanction? Can the agency provide case examples that portray welfare recipients as hard workers?

"Client-friendly" modifications to agency programs and services may also be required when public policy shifts are considered to be against the best interests of 
the users of service. The agency's information and referral services may need to be expanded to include a broader number and type of training programs or day care services in the community that can accommodate working clients (Hagen, 1999). The budget may need to be revisited to establish a small emergency fund to assist clients with transportation to job interviews. Periodic revisiting of the extent to which the agency's services help, rather than hinder clients can address environmental issues at the most basic level-that of service provision.

\section{Empowering Individual Clients}

Clinical interventions and advocacy share the common goal of helping clients become independent and exercising influence and control over their own lives. The concept of empowerment, a central focus of an advocacy approach with individual clients, comes largely from a clinical framework (Hegar \& Hunzeker, 1988; Hegar, 1989; Simon, 1990; Simon, 1994). The flip side of empowerment-a lack of power-has been identified in an increasing number of psychiatric patients as being the root cause of their mental disorders-a result of external influences rather than internal conflicts (Mack, 1994). The importance of empowerment is evident in the characteristics and status of modern society; powerlessness may be the cause of many of the psycho-social problems experienced by citizens today (Etizoni, 1991; Haynes \& Mickelson, 1996). Empowerment is thus an essential component of treatment to help clients take control of their lives, often by emphasizing strengths rather than pathologies, and intervening to affect change in environmental conditions that are harmful. Empowerment involves the imparting of valuable life skills that go beyond the specific situation or condition.

The use of advocacy as an intervention in working with individuals, families, or small groups is also affected by how the client's relevant environment is defined. Often, the environment is construed as immediate, both emotionally and geographically, thus orienting advocacy interventions to those conditions that are visible, locale, and/or concrete in nature. A social worker assisting a client on public assistance may devise empowerment strategies to help that client effectively negotiate the welfare bureaucracy. However, the focus is then on the client's specific circumstance, and not the larger political and economic issues that underlie welfare dependency.

A social worker who works directly with welfare recipients within an agency context can incorporate several protocols that would expand the definition of the client's environment and, hence, what strategies are available to change it. Procedures for agency intake, for example, may be revised to include raising with the client directly the question of what larger environmental/political conditions may affect the quality of her life, now and in the future. To illustrate, early in the welfare reform debate, a client intake protocol might have included questions about how proposed legislative changes would affect options for job training or education. If proposed changes were documented as detrimental, such as precluding the development of the skills needed to secure a job at a decent wage, the social worker could abstract such information as part of an overall agency response. The social work also could discuss with the client how she might advocate on her own behalf. Is, for example, the client interested in telling her story to her legislative representative who may be voting on a proposal?

Empowerment as a component of clinical intervention includes encouraging citizen participation in the political process, particularly when the proposed legislation will have a direct and immediate impact on clients' lives (Gamble \& Wells, 1995; Haynes \& Mickelson, 1996). Information elicited in this manner may also be stored in central "advocacy" files for use in documenting and supporting, in aggregate form to protect confidentiality, the advocacy position taken by the agency.

A component of the psycho-social history, reflected in the case record, would thus be devoted to environmental/political issues and the case plan would address short and longer term goals related to client empowerment. Goals and strategies would be constantly reviewed through worker-client interactions to monitor progress and identify new or better ways to achieve individual goals. This would also require the social worker to expand the definition of the resources available to the client to effectuate these goals. For example, the worker would have to be knowledgeable about relevant advocacy groups in the community, or how such groups might be organized if none exist.

Models for integrating advocacy as a core intervention in the helping process have been successfully demonstrated in work with other vulnerable populations. AIDS activists, for example, seized the concept of empowerment and successfully influenced how quickly the Federal Drug Administration (FDA) approved experimental drugs, how much monies were allocated for research, and what public measures were put into place to prevent the spread of AIDS among high risk groups (Hanley, 1988; Icard \& Schilling, 1992; Wachter, 1992). This rare blending of micro and macro advocacy strate- 
gies provides a model for empowering other vulnerable groups, such as welfare recipients. The social work role consists of helping clients to identify and consider strategies to change environmental conditions that affect their lives. The social worker then assists the client in implementing the strategy. It is the client who is the doer and the worker the facilitator.

\section{Participating in the Public Arena}

\section{Cause Advocacy}

Advocacy at the macro level, or cause or class advocacy, refer to those interventions to change the environment on behalf of many clients in similar circumstances (Mickelson, 1995). It encompasses a range of activities in the political sphere, among them educating and lobbying decision-makers (legislators) and opinion makers (the media), and building coalitions. The approach is typically pragmatic, emphasizing consensus building, data collection and research, and the use of mainstream administrative channels to affect change (Dluhy, 1990; Richan, 1991; Smucker, 1991; Haynes \& Mickelson, 1996). Many smaller human service agencies may see advocacy at this level as outside of their resources or expertise, but this is not the case. Significant influence can be exercised, as discussed below, through the use of the media and through collaborations with other agencies.

\section{Monitoring the Environment}

The first step in any advocacy campaign is to know when to start it. A crisis, such as the imminent passage of regressive legislation or the elimination of funding for a program, may trigger a surge of activity, but effective action may be too late. Monitoring legislative trends on issues affecting the agency's clients on a regular basis allows issues to be identified in the "germination" stage, before they burst full blown on the public agenda, when positions are often hardened and solutions frequently predetermined.

The year 1996, when TANF was passed, was actually the end of a debate that had begun in earnest in the early 1990s when many states experimented with a variety of welfare reforms. The common thread in many of these reforms was the increased emphasis on work, utilization of sanctions against recipients who did not comply with work requirements, and a reduction of training and educational opportunities for welfare recipients (Handler, 1995). Burgeoning animosity toward welfare recipients was exemplified in public attitudes which held that most recipients were not employed and did not want to work (Cammisa, 1998). While specific federal legislation had yet to be introduced in Congress, all indicators pointed to a growing likelihood that welfare reform would again be placed on the national agenda. An alert and proactive advocacy effort in the early $1990 \mathrm{~s}$ might have neutralized some of the more value-based and unfounded public attitudes.

\section{Advocacy Takes Planning}

A systematized advocacy effort is predicated upon an established plan detailing the "how, who, when, and what" for intervening in the political process around a specific issue (Gibelman \& Kraft, 1996). Decisions about the position of the agency in regard to public policy fall to the Board of Directors, as advocacy initiatives involve a public stand with implications for the agency's mission, its funding base, and the allocation of its resources. Clarity about the agency's position is a prerequisite for forming alliances with other groups.

The position adopted by the agency's board may be general, e.g., stop the enactment of welfare reform legislation that may be harmful to clients, or more specific, e.g., expand the types of day care providers eligible for reimbursement to assist clients who must now work in exchange for welfare benefits. The social welfare community has been criticized for political naivete-for example, asking for "more" when "doing more with less" is the political and social current (Payne, 1996). Acknowledging and working within the context of public/political sentiments increases a group's credibility and offers a framework for formulating an advocacy agenda. However, advocates should also be aware of the crucial role they can play, at times, in defining the outer limits of the debate by offering the most radical and challenging counter version of mainstream and/or conservative opinion.

Social service agencies, particularly smaller agencies, may well lack the personnel to mount and monitor a cause-oriented advocacy campaign, in which case the board may assume responsibility for implementing the plan. Task delegation, however, should take into account who will make the most persuasive, credible and effective presentation or who knows the "right" people. Some board members, for example, may have contacts in the community that they can use to build coalitions. On the other hand, an articulate front line worker who is knowledgeable and can provide real-life examples of the daily tribulations of clients may be the most effective spokesperson at a legislative hearing. More convincing may be the welfare recipient herself. 


\section{Coalition Building}

It is axiomatic that there is strength in numbers. Coalition building is an essential component of any advocacy campaign whether at the local, state, or national level. Too often, however, coalition building occurs only among "like-minded" people, diluting its impact. Particularly with such an unpopular group as welfare recipients, advocates need to look beyond the usual allies in coalition building (Dluhy, 1990; Haynes \& Mickelson, 1996).

The homeless rights movement originating in the early 1980s in New York City is an instructive example of the effective use of coalitions. That movement successfully replaced the image of the "bowery bum" with a more sympathetic picture of the homeless as victims of an unfeeling bureaucracy and callous society. It did this, in part, by involving members of the "establishment" not usually associated with the struggles of the poor, including the Wall Street legal community, which initially funded and supported much of the early litigation on the homeless issue (Nieves, 1999). If such as unlikely ally as Wall Street corporate attorneys can be moved to support the rights of the homeless, then certainly a similar strategy can be initiated on behalf of welfare recipients.

Social service agencies are in a position to locate these unlikely allies. Typically, agency board members are from, or have ties to, the business community and community leaders outside of the social services sphere. Such people can be enlisted in the agency's advocacy cause, beyond the usual appeals for funds, to help build coalitions with groups not traditionally aligned with welfare recipients. Of course, coalitions of like-minded agencies are also necessary; a consistent and loud message emanating from a group of agencies that share similar concerns and clients affords credibility and provides a cohesive and consistent point of view.

\section{Directing the Message}

Critical to the advocacy process is being heard in the public arena, particularly by decision makers, primarily legislators and those government bureaucrats who implement policies enacted by Congress or state legislatures (Stoesz, 1993). Monitoring the political environment includes identifying key legislators and regulators involved in welfare reform. There may be formal occasions for presentations to these key players, such as congressional, state legislative, or administrative hearings. Presentations to such individuals must be carefully tailored, blending facts, emotions, and values that take the ideology and interests of the audience into account (Lens, 2000). In such a political climate, arguing "harm to children" is likely to be more effective than arguing on be- half of their parents (welfare mothers). It is significant, in this regard, that welfare reform enacted in 1988 was named "The Family Support Act" to attract support from conservatives (Jansson, 1998).

Timing is again important. A legislator's interest in issues is cyclical, with a multitude of issues appearing, and then disappearing, from the legislative agenda. Sometimes, a "window of opportunity" appears (Kingdon, 1984) where certain events (an election, a dramatic media story) stir up interest in an issue and goad legislators into action. This is the opportunity to lobby a legislator armed with documentation and alternative proposals. The time factor is critical when specific legislation is on the agenda. Welfare reform appeared on the legislative agenda in 1994 (Clinton's plan) and again in 1995 and 1996 (the Republican plan) (Cammisa, 1998). The re-surfacing of the same issue in different legislative form highlights the need for on-going monitoring and a high level of readiness to intervene quickly.

Relationships with key legislators that are continuous, rather than initiated when a group wants something, promote a more receptive hearing of advocates' ideas. Thus, the opportune time to lay the groundwork and forge relationships with legislators is before specific proposals on welfare reform appear on the legislative agenda, but while reform is clearly in the offing.

\section{Using the Media}

While laws emanate from legislatures, it is the pages of the daily newspapers and other forms of media that shape the debate, often setting the agenda for public policy (Iyengar, Peters, \& Kinder, 1982; Protess \& McCombs, 1991). Sometimes this link between the media and public policy can be almost instantaneous, as when a front-page story on Monday becomes a legislative proposal on Tuesday. In 1994, for example, the Boston newspapers carried the sensational story about ErnestoVenturo, a four-year-old boy abused by his mother. Ernesto's mother, it was alleged, had scalded his hands with boiling water and then kept him locked up for weeks without medical care. Ms. Ventura was on public assistance, with five other children and pregnant with a sixth (Sennott, 1994a). The breaking story was followed by a more indepth article that chronicled the family's four-generation dependency on welfare, at a cost of between $\$ 750,000$ to $\$ 1$ million (Sennot, 1994b).

Within days the story quickly became fodder for a debate on welfare reform that had begun in the Massachusetts Senate one week before the story appeared. On the floor, Senators peppered their speeches with ref- 
erences to the Ventura family, accompanied by claims that welfare reform would stop such a tragedy from happening (Williams, 1995). On the strength of the story, even harsher proposals for reforming welfare were considered and, within days and with little further debate, a bill was passed limiting eligibility to two years for AFDC recipients over 18 years of age.

As this example demonstrates, the media is an essential link in the advocacy chain, especially with such a volatile and emotional issue as welfare reform. Dealing with the media requires a specific set of skills (Fox \& Levin, 1993). The task is not merely to provide information to the media, but to shape and mold that information in a way that advances the advocate's position. This means, in essence, constructing a public relations campaign. Such skills can be developed or applied through alliances with those who already possess the requisite skills. Numerous guidebooks have been developed to help human service agencies develop the capacity to mount an effective media campaign (see, for example, Dobmeyer, 1997; Lauer, 1997; Radtke, 1997; Salzman \& Salzman, 1998; Bonk, Griggs, \& Tynes, 1999).

As past social change movements demonstrate, the power of a particular image propagated through the media can make a significant difference. For example, Geraldo Rivera's television expose, in the 1960s, of the atrocious conditions at Willowbrook, a residential center for the mentally ill and disabled, gave enormous impetus for the deinstitutionalization movement. Models for constructing a public relations campaign on behalf of welfare recipients advocates can also be found in the successful public education drives of MADD (Mothers Against Drunk Drivers) and the anti-smoking campaigns and pro seat belt use of the last few years. These efforts molded not only public attitudes, but also public behavior.

What such efforts have in common is a coordinated and conscious effort to influence what the media reports. Telling clients' stories to the media, to legislators, and to other citizens, can be one of the most crucial roles social workers can play (Schrader, 1996; Withorn, 1998). Successful advocates seek out the media rather than wait for the rare opportunity when the media comes looking for a story. It requires such tactics as discerning which reporters are sympathetic to the plight of people on welfare and cultivating a relationship with them. It means finding the "right" human-interest story to push in the media and paying attention to the use of language, rhetoric and symbols when interacting with the media. The agency's own records and statistics can provide the raw material for fact-based, human interest stories.

A public relations campaign on behalf of welfare recipients also means fostering relationships with some unlikely people to encourage them to act as public spokespeople. If a business leader in the community or a celebrity compassionately tells about the struggles of welfare recipients, the impact is significantly greater than if an unknown person articulates the same struggles. In this regard, both the AIDS and breast cancer education initiatives significantly increased positive media coverage by utilizing charismatic spokespersons. The recent decision of Michael J. Fox to leave his successful television sitcom and devote himself full-time to advocate for research funds for Parkinson's Disease was a leading media story that brought attention to the disease and search for a cure.

Such a campaign can also mean using what has until now been considered primarily the province of business: advertising. In a recent example of this approach, Harvard University provided a $\$ 100,000$ grant to fund a series of public service advertisements, using celebrities, to convince citizens to support the homeless (Lueck, 1999). Advertisements such as these have a major advantage because the image projected and the message sent can be completely controlled by the advocates, rather than filtered through the lens of a journalist. Finding a celebrity spokesperson requires connections and work. A largescale advertising campaign involves collaborative efforts within and beyond the social welfare community.

In fund-raising appeals, information brochures, and other material seen by the public, an agency can incorporate images and messages that enhance the image of welfare recipients. A more favorable image of welfare recipients is essential for positive reform. A population that is described negatively has the most to lose from the policymaking process (Schneider \& Ingram, 1993). Socially or politically unpopular groups serve as lightening rods, especially around election time as politicians attempt to scapegoat them for the sake of votes. The press is neither benign nor neutral; its messages are a powerful force in influencing public opinion (Edelman 1988; Zaller, 1992). The social welfare community seeking to influence the course of welfare reform needs to be sensitive to the crucial role of the media in creating these images.

\section{Moving Forward}

The analysis of the limited role of the social work profession in the welfare reform debate reveals a number of principles that may be utilized by practitioners and 
their employing agencies to ensure a more significant voice in the future. Table 1 summarizes these principles, which are presented in descending order, beginning with principles that apply at the practitioner level, intra-agen$\mathrm{cy}$ and, last, inter-agency level. These principles also suggest a series of action strategies.

The advocate's role is continuous, as are the policy issues they seek to influence. Welfare reform has already been re-visited, with some positive results (such as removing some of the harshest measures oriented toward immigrants). New themes are appearing in the public discourse, from "compassionate conservatism" to "child poverty" that may indicate a slight softening toward welfare recipients, or at least their children. With the clock ticking rapidly toward the year 2001, when the five-year limit time on TANF benefits takes affect, the time is now for advocates to tap the public and political pulse and come forward with realistic and pragmatic legislative proposals, targeted at key legislators, that address some of TANF's deficiencies.

\section{Conclusion}

The passage of TANF is by no means the end of the policymaking process. Advocacy strategies are needed as much now as they were before the law was passed. As

TABLE 1: Lessons Learned and Guidelines for the Future

Principles

Advocacy is a core social work function at all levels and types of practice.

Know the extent to which social policy impacts on clients' lives.

Document and quantify human needs and socio-political impacts.

Communicate client strengths as well as pathologies; mobilize clients to effectively negotiate systems

Individual stories about the potential or actual impact of social policies lends real names and faces to otherwise abstract concepts

When it's everyone's job, it's no one's job; use contacts and talents of the board, staff, clients

Ensure staff has the requisite competencies to be an effective voice.

Anticipate change.

Reform legislation often affects a broad range of programs and services, beyond the obvious target of change.

Respond early and quickly to legislative proposals.

Gauge political climate; "credible" positions carry weight.

Articulate policy positions.

Emphasize hard facts and constructive alternatives.

Testify using strategies that take into account the ideas and interests of the audience.
Implications

Include advocacy as a component of each professional job description; specify advocacy issues and strategies in case planning.

Periodically assess the extent to which environmental conditions affecting clients are being addressed.

Include environmental impact as part of intake procedures; maintain records that highlight how social policies impact upon individual clients; periodically aggregate and analyze case record data.

Incorporate empowerment strategies into practice; expand definition of the client's environment.

Encourage client participation in the political process

Assign responsibility in the advocacy effort - who is to do what? Who is most capable of doing what.

Encourage an "advocacy mind-set" through staff development and administrative sanction.

Monitor legislative developments consistently; identify key legislators; keep staff informed about pending legislative changes

Fully analyze legislative implications.

Timing is critical; maintain level of preparedness; intervene early, before positions are hardened

Offer proposals that are "real" within the political environment.

Board of Directors must decide and vote upon its position; position must be clear and cohesive.

Avoiding arguing the status quo

Know about hearings and how to get on the calendar. 
Principles

The media is a powerful means of communicating positions; media reports can be "shaped".

Get the word out.

There is power in numbers.

The process is continuous; policy is re-visited.

Blumer (1971) emphasized, policymaking is a cyclical process, with implementation the start of a "new process of collective definition" (p. 304) which begins as the unanticipated consequences of the policy become evident and modifications become necessary. Advocates must now take advantage of the window of opportunity that occurs during this experiential and evaluative phase of welfare reform.

Advocating on behalf of welfare recipients represents perhaps one of the most difficult challenges facing the social welfare community. A retrospective look at how the social welfare community might have organized more effectively to advocate for less punitive welfare reforms offers important lessons that can be applied to the multitude of problems and issues confronting social workers and their clients. Chief among them is that advocacy is an essential and ongoing component of professional practice that is both consistent with ethical mandates and the "person-in-environment" orientation that is the special province of social work practice. It requires the social worker to ask the following questions in every encounter with clients: What can I do to empower my clients to change their immediate environment to make it more responsive to their needs? What can I do to change the policies and practices of my agency that may be adversely affecting my clients? What can I do to influence public policy that directly and negatively impact upon my client?

Advocacy is a much more potent tool when it is used proactively to influence and shape the course of events rather than respond to them. At a time when "doing more with less" can easily result in staff burnout, advocacy may have the added benefit of empowering the social welfare community, as well. Working effectively to influence the political environment through advocacy makes social workers "players," rather than passive victims to the decisions of others.
Implications

Develop requisite skills to work effectively with the media; strengthen capacity to mount an effective media campaign.

When possible, have a celebrity spokesperson.

Form alliances and coalitions with other groups and agencies; look beyond usual alliances beyond the social services arena.

Always be ready.

\section{References}

Abbott, A. A. (1993, November). In tune with the times of reform. NASW News, p. 2.

Barker, R. L. (1999). The sacial work dictionary, 4th ed. Washington, DC: NASW Press.

Blumer, H. (1971). Social problems as collective behavior. Social Problems, 18, 298-306.

Bonk, K., Griggs, H., \& Tynes, E. (1999). The Jossey-Bass guide to strategic communications for nonprofits: A step-by-step guide to working with the media to generate publicity, enhance fun. San Francisco, CA: Jossey-Bass.

Cammisa, A. (1998). From rhetoric to reform? Boulder, CO: Westview Press.

Council on Accreditation (1997). 1997 standards for behavioral health care services and community support and education services, United States edition. New York: Author.

Council on Social Work Education. (1994). Handbook of accreditation standards and procedures. Alexandria, VA: Author.

Dluhy, M.K. (1990). Building coalitions in the human services. Newbury Park, CA: Sage.

Dobmeyer, D. (1996). Competing successfully for media coverage. Chicago, IL: Dobmeyer Communications.

Edelman, M. (1988). Constructing the political spectacle. Chicago: University of Chicago Press.

Emenhiser, D.L. King, D.W., Joffe, S.A., \& McCullough, C. (1998). Networks, mergers, o partnerships in a managed care environment. Washington, DC: Child Welfare League of America.

Etzioni, A. (1991). A responsive society. San Francisco, CA: Jossey-Bass.

Fox, J.A., \& Levin, J. (1993). How to work with the media. Thousand Oaks, CA: Sage.

Gamble, D.N. \& Weil, M.O. (1995). Citizen participation. In Edwards, R.L. (ed.-in-chief). Encyclopedia of Social Work, 19th edition, pp. 483-494. Washington, DC: NASW Press.

Gibelman, M., \& Kraft, S. (1996). Advocacy as a core agency program: Planning considerations for voluntary human services agencies. Administration in Social Work, 20 (4), 43-59.

Gibelman, M., \& Schervish, P. (1996). The private practice of social work: Current trends and projected scenarios in a managed care environment. Clinical Social Work Journal, 24 (3), 321-338.

Gibelman, M., \& Schervish, P. (1997). Who we are: A second look. Washington, DC: NASW Press.

Hagen, J. (1999). Public welfare and human services: New directions under TANF? Families in Society, 80 (1), 78-90. 
Handler, J. (1995). The poverty of welfare reform. New Haven, CT: Yale University Press.

Hanley, P. (1988). Providing empowerment to the person with AIDS. Social Work, 33, 251-253.

Harmon, G.M., Ladd, J.A., \& Evans, E.A. (1997). Being a player: A guide to the IRS lobbying regulations for advocacy charities. Washington, DC: Alliance for Justice.

Hartman, A. (1993). The professional is political. Social Work, 38, $365-366$

Havemann, J. (1995, October 6). Liberal advocacy groups urge veto of welfare bill. Washington Post, p. A11.

Haynes, K.S., \& Michelson, J.S. (1996). Affecting change: Social workers in the political arena, 3rd ed. Reading, MA: Addison-Wesley.

Hegar, R.L. (1989). Empowerment-based practice with children. Social Service Review, 63, 372-383.

Hegar, R.L. \& Hunzeker, J.M. (1988). Moving toward empowerment-based practice in public child welfare. Social Work, 33, 499-502.

Hiratsuka, J. (1990). Community Organization; assembling power. NASW News, p. 3.

Hopkins, B. (1991). Charity, advocacy, and the law. New York: John Wiley.

Icard, L.D., \& Schilling, R.F. (1992). Preventing AIDS among black gay men and black gay and heterosexual male intravenous drug users. Social Work, 37, 440-445.

Iyengar, S., Peters, M., \& Kinder, D. (1982). Experimental demonstrations of the 'not so minimal' consequences of television news programs. American Political Science Review, 76, 848-858.

Jansson, B. (1998). Becoming an effective policy advocate. Pacific Grove, CA. Brooks/Cole.

Kahn, S. (1991). Organizing: A guide for grassroots leaders. Silver Spring, MD: NASW Press.

Kingdon, J.W. (1984). Agendas, alternatives, and public policies. Boston, MA: Little, Brown.

Lauer, L.D. (1997). Communication power: Energizing your nonprofit organization. Frederick, MD: Aspen Publishers.

Lens, V. (2000). Welfare reform and the media. Unpublished doctoral dissertation. New York: Yeshiva University, Wurzweiler School of Social Work.

Lueck, T. (1999, December 15). Housing Secretary chides mayor for criminalizing the homeless. New York Times, p. B3.

Mack (1994), Psychotherapy and society: Power, powerlessness, and empowerment in psychotherapy. Psychiatry, 57, 178-198.

Mickelson, J.S. (1995), Advocacy. In R. L. Edwards (Ed.-in-chief). Encyclopedia of Social Work, 19 th edition, pp. 95-100. Washington, DC: NASW Press.

National Association of Social Workers, (1996a). Code of ethics. Washington, DC: Author.

National Association of Social Workers. (1996b, August 27). Personality Responsibility and Work Opportunity Reconciliation Act of 1996: Summary of provisions. Government Relations Update. Washington, DC: Author.

Nieves, E. (1999, December 7). Cities try to sweep homeless out of sight. New York Times on line: http:/www.nytimes.com/news/national/sanfran-homeless.html

Payne, J.L. (1996, December 9). Social workers could undermine welfare reform. Bergen Record, p. A16.

Personal Responsibility and Work Opportunity Reconciliation Act of 1996 (P.L.104-193), 42 U.S.C. 1305.
Protess, D., \& McCombs, M. (Eds.). (1991). Agenda setting: Readings on media, public opinion, and policymaking. Hillsdale, NJ: Erlbaum.

Radtke, J.M. (1998). Strategic communications for nonprofit organizations: Seven steps to creating a successful plan. Somerset, NJ: John Wiley \& Sons.

Richan, W.C. (1991). Lobbying for social change. New York: Haworth Press. Salzman, J., \& Salzman, J. (1998). Making the news: A guide for nonprofits and activists. Boulder, CO: Westview Press.

Schneider, A., \& Ingram. H. (1993). Social construction of target populations: Implications for politics and policy. American Political Science Review, 87, 334-347.

Schadler, B.H. (1996). Nonprofit organizations, public policy, and the political process: A guide to the Internal Revenue Code and Federal Election Campaign Act. San Francisco, CA: The Tides Center.

Schrader, J. (1996, August 25). Welfare as I know it: A Virginia casework tells how her clients' lives are already changing. Washington Post, C1, C4.

Sennott, C. (1994a, Feb.14). Abuse case stirs alarm. Boston Globe, p.19.

Sennott, C. (1994b, Feb.20). Finding four generations sustained by welfare. Boston Globe, p. 1.

Simon, B. L. (1990). Rethinking empowerment. Journal of Progressive Human Services, 1(1), 27-39.

Simon, B. L. (1994). The empowerment tradition in American social work. N>Y> Columbia University Press.

Smucker, B. (1991). The nonprofit lobbying guide: Advocating your cause-and getting results. San Francisco, CA: Jossey-Bass.

Specht, H., \& Courtney, M. (1994). Unfaithful angels: How social work has abandoned its mission. New York: Free Press.

Staff. (1993, February). "Teach-ins" bash welfare misconceptions. NASW News, pp. 6-7.

Stoesz, D. (1993). Communicating with the public. Social Work, $38,367-368$.

Super, D.A., Parrott, S., Steinmetz, S., \& Mann, C. (1996, August 14). The new welfare law. Washington, DC: Center on Budget and Policy Priorities.

Vobejda, B., \& Havemann, J. (1995, May 21). Traditional welfare constituencies put out by lack of input in reform. Washington Post, p. A4.

Wachter, R.M. (1992, January 9). AIDS, activism, and the politics of health. New England Journal of Medicine, 326, 128-133.

Williams, L. (1995). Race, rat bites and unfit mothers: How media discourse informs welfare legislation debate. Fordham Urban Law Journal, 22, 1159-1196.

Withorn, A. (1998). No win: Facing the ethical perils of welfare reform. Families in Society, 79(4), 277-287.

Zaller, J. (1992). The nature and origins of mass opinion. Cambridge, MA: Cambridge University Press.

Vicki Lens is clinical instructor and Margaret Gibelman is professor and director, doctoral program, Veshiva University, Wurzweiler School of Social Work, 2495 Amsterdam Avenue, New York, NY 10033.

Original manuscript received: March 10, 2000

Accepted: April 27, 2000 